\title{
Dharma and ecology of Hindu communities: sustenance and sustainability. By Pankaj Jain. Farnham, Surrey, U.K.: Ashgate, 2011. 213 pages
}

\author{
Christopher Key Chapple
}

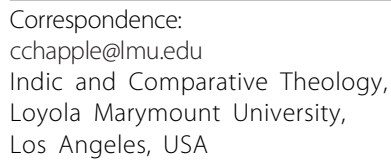

Indic and Comparative Theology, Loyola Marymount University, Los Angeles, USA

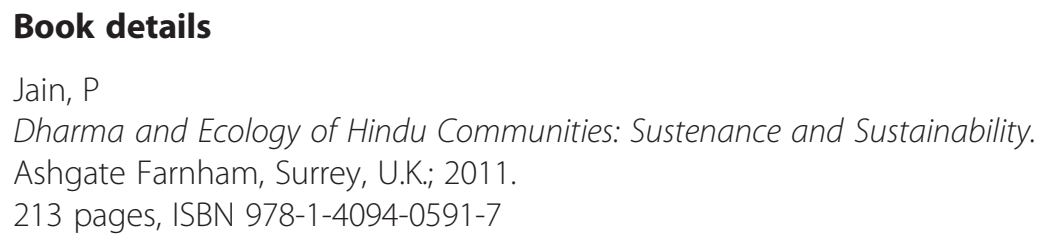

Keywords: Dharma; Ecology; Hinduism; Chipko; Bishnoi; Svadhyaya; Bhils

Pankaj Jain has created a pioneering book in the important and newly emerging field of religion and ecology. In Dharma and Ecology of Hindu Communities, he presents research on three communities in India that, from the outside, seem to profess and practice forms of environmental activism. The book, based on his dissertation at the University of Iowa, begins with an analysis of conceptual approaches to religious environmentalism in India, including devotional and ascetic models. The bulk of the book examines three vital communities in different regions of India: the Svadhyaya movement, the Bishnoi community, and the lifestyle of the Bhil tribal community. The book ends by suggesting that the flexibility of the South Asian ethos of dharma lends itself to providing tools to cope with impending ecological challenges.

The Svadhyaya movement of Gujarat seeks to educate people through mass literacy campaigns inspired by the Bhagavad Gita. The movement was founded by Pandurang Shastri Athavale (1920-2003), winner of the Templeton Prize. In addition to promoting literacy, Svadhyaya members also promote mass plantings of trees. Though they do not self-define as an environmental organization, Jain demonstrates the effectiveness of their village projects. He posits that the Svadhyayis practice neither a form of "utilitarian conservationism" nor "protectionist conservationism" as defined by Anil Agarwal (Chapple and Tucker 2000) but act with environmental consciousness from a devotional motive instead.

The founder of the Bishnoi community, Guru Jambeshwara, was born in 1451 and, in response to a paralyzing drought in his native Rajasthan, developed a code for behavior to stretch meager resources of water and food. These 29 rules became the foundation for a new faith that combines aspects of Hindu and Muslim sensibilities. The tree-hugging event associated with the Bishnois movement of Rajasthan arose more than two hundred years ago when several hundred people lost their lives in order to 
save a stand of trees from being destroyed. On Tuesday, September 9, 1730, Amrita Devi and her family hugged trees in order to save them from being destroyed by the solders of Maharaja Abhay Singh, King of Jodhpur, who wanted the trees for a government construction project. One by one, 363 members of this tribal group were felled along with the trees, in a failed attempt to save an important aspect of their livelihood. This action served as the model for the 20th century Chipko movement that similarly resisted the destruction of forests in Uttarakhand, slated to be harvested for the manufacture of sporting goods. The Bishnois continue to be renowned for their protection of animals and forests. Pankaj Jain has provided a great service by reporting in detail on their history and, for the first time, translating their primary scriptures into English.

The Bhil tribe, by virtue of their subsistence lifestyle, lives close to the land and in harmony with nature, though overpopulation and the pressures of urbanization and market capitalism threaten their existence. Jain describes the sacred groves maintained though a cooperative venture between the government of India and the Bhils, noting that these groves in Rajasthan serve "religious, economic, and social functions" in addition to serving as habitat for multiple species of animal including Langur monkeys, leopards, hyenas, jackals, fox, porcupines, spotter deer, bears, and antelope.

By spending time with each of these communities, by recording detailed interviews, and by translating core documents for the Bishnoi and the Svadhyayis, Pankaj Jain has done a great deal to advance our knowledge of indigenous ecological knowledge systems in India. This book is ideal for an upper division or graduate course in religion and ecology and should be part of every college and university library collection.

Competing interests

The author declares that he has no competing interests.

\section{Submit your manuscript to a SpringerOpen ${ }^{\circ}$ journal and benefit from:}

- Convenient online submission

- Rigorous peer review

- Immediate publication on acceptance

- Open access: articles freely available online

- High visibility within the field

- Retaining the copyright to your article

Submit your next manuscript at $>$ springeropen.com 